\title{
Cosmic Order and Divine Power
}

\section{Pseudo-Aristotle, On the Cosmos}

Introduction, Text, Translation and Interpretative Essays by Johan C. Thom, Renate Burri, Clive Chandler, Hans Daiber, Jill Kraye, Andrew Smith, Hidemi Takahashi, Anna Tzvetkova-Glaser. Ed. by Johan C. Thom

[Kosmische Ordnung und göttliche Macht. Pseudo-Aristoteles, Über den Kosmos .]

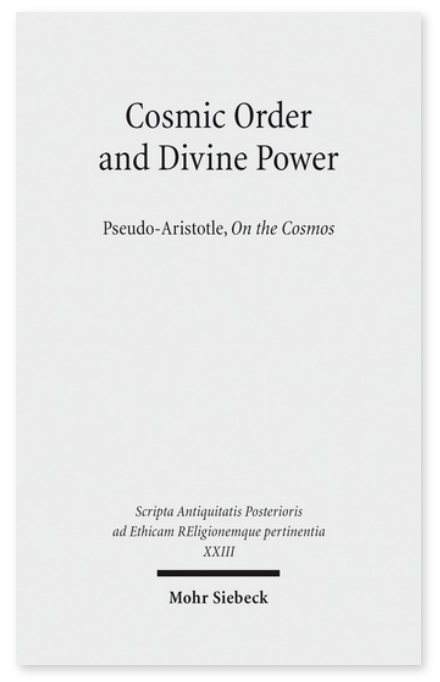

2014. X, 230 Seiten. SAPERE XXIII

ISBN 978-3-16-156432-1

DOI 10.1628/978-3-16-156432-1

eBook PDF

ISBN 978-3-16-152809-5

Leinen $59,00 €$
Veröffentlicht auf Englisch.

Die Abhandlung De mundo (Über den Kosmos), die auf das 1. Jahrhundert v. Chr. datiert wird, bietet eine Kosmologie in peripatetischer Tradition dar, wobei platonische und stoische Denkfiguren mit einfließen. Alle Geschehnisse im Kosmos werden der Herrschaft eines allmächtigen Gottes untergeordnet. Aus diesem Grund ist das Werk paradigmatisch für philosophische und religiöse Konzepte der frühen römischen Kaiserzeit, die Berührungspunkte mit dem entstehenden Christentum aufweisen. Der Band enthält den griechischen Text und die Übersetzung von De mundo, sowie erläuternde Essays über Sprache und Stil, Geographie, Kosmotheologie und Rezeptionsgeschichte.

Johan C. Thom Born 1954; Studied at the Universities of Stellenbosch, Pretoria, and Chicago; 1990 PhD; Professor of Classics at the University of Stellenbosch.

Renate Burri ist Doktorandin in Klassischer Philologie an der Universität Göttingen.

Clive Chandler teaches in the Classics Section of the School of Languages and Literatures at the University of Cape Town. His research interests lie in the intellectual history of Greece (especially, but not exclusively, Epicurean philosophy), rhetoric, and ancient commentaries on Homer.

Hans Daiber was holder of the chair of Oriental Languages at the Johann Wolfgang Goethe-Universität Frankfurt am Main. His main fields are Arabic and Islamic Studies, including Islamic philosophy, theology, history sciences and the field of Greek / Syriac / Arabic / Latin translations as well as analyzing and describing Arabic manuscripts.

Jill Kraye is an Honorary Fellow and former Librarian of the Warburg Institute, University of London. She specializes in the history of Renaissance philosophy and humanism, with a particular interest in the later influence of the ancient philosophical schools.

Andrew Smith was Professor of Classics, University College Dublin. He is Associate Director of the Plato Centre, Trinity College Dublin, and joint editor of a series of philosophical commentaries on Plotinus.

Hidemi Takahashi teaches in the Graduate School of Arts and Sciences at The University of Tokyo. His main field of research is in Syriac Studies, especially the reception of the Greek sciences in Syriac and the works of the thirteenth-century author Gregory Barhebraeus.

Anna Tzvetkova-Glaser is lecturer of Ancient Greek at the Faculty of Theology of the University of Heidelberg. Among her scholarly interests are early Christian literature (especially Origen) and the relationship between Judaism and Christianity in the first centuries AD. She has also worked on Augustine's polemic against the Semi-Pelagians.

Jetzt bestellen:

https://mohrsiebeck.com/buch/cosmic-order-and-divine-power-9783161564321?no_cache=1

order@mohrsiebeck.com

Telefon: +49 (0)7071-923-17

Telefax: +49 (0)7071-51104 